\title{
Absence of the mdr1a P-Glycoprotein in Mice Affects Tissue Distribution and Pharmacokinetics of Dexamethasone, Digoxin, and Cyclosporin A
}

\author{
Alfred H. Schinkel, Els Wagenaar, Liesbeth van Deemter, Carla A. A. M. Mol, and Piet Borst \\ The Netherlands Cancer Institute, Division of Molecular Biology, Plesmanlaan 121, 1066 CX Amsterdam, The Netherlands
}

\begin{abstract}
We have previously shown that absence of the mouse mdr1a (also called mdr3) P-glycoprotein in mdrla (-/-) "knockout" mice has a profound effect on the tissue distribution and elimination of vinblastine and ivermectin, and hence on the toxicity of these compounds. We show here that the mouse mdr1a and the human MDR1 P-glycoprotein actively transport ivermectin, dexamethasone, digoxin, and cyclosporin $A$ and, to a lesser extent, morphine across a polarized kidney epithelial cell layer in vitro. Injection of these radiolabeled drugs in mdrla $(-/-)$ and wild-type mice resulted in markedly (20- to 50-fold) higher levels of radioactivity in mdrla (-/-) brain for digoxin and cyclosporin $A$, with more moderate effects for dexamethasone (2- to 3-fold) and morphine (1.7-fold). Digoxin and cyclosporin $A$ were also more slowly eliminated from mdrla $(-/-)$ mice. Our findings show that P-glycoprotein can be a major determinant for the pharmacology of several medically important drugs other than anti-cancer agents, especially in the blood-brain barrier. These results may explain a range of pharmacological interactions observed between various drugs in patients. (J. Clin. Invest. 1995. 96:1698-1705.) Key words: multidrug resistance $\bullet$ blood-brain barrier $\bullet$ morphine $\bullet$ reversal agents - neurotoxicity
\end{abstract}

\section{Introduction}

Upon selection with a single cytotoxic drug, mammalian cancer cells can develop resistance against a range of drugs with different structures and intracellular targets. This phenomenon, called multidrug resistance, can be caused by P-glycoproteins, 140$170-\mathrm{kD}$ plasma membrane proteins that actively extrude a wide range of amphiphilic hydrophobic drugs from the cell (1-5). Many of these drug substrates are toxic compounds of natural or semisynthetic origin that are extensively used in the chemotherapy of cancer (e.g., Vinca alkaloids, anthracyclines, epipodophyllotoxins, taxanes) but also for a variety of other medical purposes such as immunosuppression (cyclosporin A, FK506) and treatment of heart disease (verapamil, digoxin).

Humans have one drug-transporting P-glycoprotein (MDR1), which is prominent in the brush border of renal proxi-

Address correspondence to Piet Borst, M.D., Division of Molecular Biology, The Netherlands Cancer Institute, Plesmanlaan, 121, 1066 CX Amsterdam, The Netherlands. Phone: 20-5122880; FAX: 20-6691383.

Received for publication 13 April 1995 and accepted in revised form 13 June 1995.

J. Clin. Invest.

(C) The American Society for Clinical Investigation, Inc.

0021-9738/95/10/1698/08 \$2.00

Volume 96, October 1995, 1698-1705 mal tubules, in the biliary membrane of hepatocytes, in the apical membrane of mucosal cells in the intestine, in capillary endothelial cells of brain and testis, in adrenal gland and in placental trophoblasts $(6-8)$. This distribution suggested that MDR1 P-glycoprotein can protect the organism against toxic xenobiotic compounds, by excreting these compounds into urine, bile, and the intestinal lumen, and by preventing their accumulation in critical organs such as brain or testis. In contrast to humans, mice have two genes encoding drug-transporting Pglycoproteins, $m d r l a$ (also called $m d r 3$ ) and $m d r l b$ (also called $m d r l)$, respectively $(2,9,10)$. The mouse $m d r l a$ gene is predominantly expressed in intestine, liver, and blood capillaries of brain and testis, whereas the $m d r l b$ gene is predominantly expressed in adrenal, placenta, ovarium and (pregnant) uterus. Similar levels of mdrla and $m d r l b$ expression are found in kidney (11-14). These data suggest that mdrla and $m d r l b$ in the mouse together fulfil the same function as $M D R 1$ in humans.

Studies of MDR1 protein and RNA levels in clinical tumor samples indicate that this protein may be relevant for intrinsic or acquired MDR in a range of tumor types (e.g., 15-17). This led to an extensive search for P-glycoprotein inhibitors. Many compounds with low cytotoxicity can inhibit P-glycoprotein activity, for instance verapamil, quinidine, cyclosporin $\mathrm{A}$ and its non-immunosuppressive analogue PSC833 (18-21). There is currently great interest in the co-administration of these socalled reversal agents in patients to reduce P-glycoprotein-mediated drug resistance of tumors during chemotherapy. Many phase I and phase II clinical trials to test the feasibility of this approach are now in progress (22-25). One major concern in this approach is the effect that P-glycoprotein inhibitors will have on the normal function of the drug-transporting P-glycoproteins. To learn more about the physiological and pharmacological role of these proteins, we have recently generated a mouse strain with a genetic disruption of the mdrla gene (mdrla (-/-) mice; 14).

The mdrla $(-/-)$ mice provided a striking confirmation of the protective role of P-glycoprotein. These mice, which do not have detectable P-glycoprotein at the blood-brain barrier, were 100 -fold more sensitive to the neurotoxic pesticide ivermectin, threefold more sensitive to the anti-cancer agent vinblastine, and they accumulated much higher levels of these drugs in their brain. In addition, they displayed overall increased accumulation of these compounds in tissues and plasma, and decreased elimination (14). Many other drugs are known to be substrates of P-glycoprotein in vitro, including morphine, one of the most widely used analgetics (26); dexamethasone, an anti-inflammatory and glucocorticoid drug (27); digoxin, a heart glycoside that is widely used in the treatment of congestive heart failure (28); and cyclosporin A, an agent that has revolutionized organ transplantation by its ability to suppress allograft rejection (29). We have therefore tested whether the in vivo distribution of these medically important drugs (30) is also affected by the absence of mdrla P-glycoprotein. Because the 
substrate specificity of P-glycoprotein variants can differ substantially $(31,32)$, we also compared the ability of the human MDR1 and the mouse mdrla P-glycoprotein to transport these drugs in vitro. This enables us to assess whether the MDR1 Pglycoprotein could affect the distribution of these drugs in humans in a similar manner as the mdrla P-glycoprotein in mice.

\section{Methods}

Materials. Ivermectin and $\left[22,23-{ }^{3} \mathrm{H}\right]$ Ivermectin $\mathrm{B} 1 \mathrm{a}(51.9 \mathrm{mCi} / \mathrm{mg})$ were kindly provided by Dr. J. Schaeffer, Merck Research Laboratories. [N-methyl- $\left.{ }^{3} \mathrm{H}\right]$ morphine $(86.5 \mathrm{Ci} / \mathrm{mmol})$ and $\left[12 \alpha-{ }^{3} \mathrm{H}(\mathrm{N})\right]$ digoxin (6.1 Ci/mmol) were obtained from Du Pont NEN (Wilmington, DE). $\left[1,2,4,6,7-{ }^{3} \mathrm{H}\right]$ dexamethasone $(87 \mathrm{Ci} / \mathrm{mmol})$, [methyl-butenyl-methylthreonine- $\beta-{ }^{3} \mathrm{H}$ ]cyclosporin A $(6.6 \mathrm{Ci} / \mathrm{mmol})$, and inuline $\left[{ }^{14} \mathrm{C}\right]-$ carboxylic acid were from Amersham (Little Chalfont, England). Cyclosporin A was from Sandoz, Basel, Switzerland, and morphine. $\mathrm{HCl}$ was from the Slotervaart Hospital Pharmacy. Other chemicals and drugs were from Sigma Chemical Co. (St. Louis, MO).

Tissue culture. LLC-PK1 pig kidney epithelial cells were obtained from the American Type Culture Collection and cultured in M199 medium supplied with L-glutamine (GIBCO BRL, Paisley, Scotland) supplemented with penicillin $(50 \mathrm{U} / \mathrm{ml})$, streptomycin $(50 \mu \mathrm{g} / \mathrm{ml})$ and $10 \%$ (vol/vol) fetal calf serum ("complete medium") at $37^{\circ} \mathrm{C}$ in the presence of $5 \% \mathrm{CO}_{2}$. Cells were subcultured by trypsinization every 3 to $4 \mathrm{~d}$.

Transfection. Human MDRI cDNA was transfected as the plasmid pFRCMVMDR1.1 $(33,34)$. The mouse mdrla cDNA (a kind gift of Dr. P. Gros, Montreal, Canada), first cloned as an AccI(blunted) -DraI fragment into the SmaI site of pGEM7 (Promega, Madison, WI), was excised using Asp718 and ClaI, blunted with Klenow DNA polymerase and cloned into Xbal-digested, Klenow-blunted pFRCMV to yield pFRCMVmdrla. This construct was transfected. LLC-PK1 cells were transfected using the calcium phosphate coprecipitation technique (35) modified as described (33). $10 \mu \mathrm{g}$ of supercoiled DNA and $10 \mu \mathrm{g}$ of salmon sperm carrier DNA was used per 10-cm Petri dish. Two days after transfection, selection was initiated with 160,320 , or $640 \mathrm{nM}$ vincristine sulphate. Colonies growing readily at $640 \mathrm{nM}$ vincristine were picked after 2-3 wk, expanded, and tested for P-glycoprotein content on protein immunoblots. Mock-transfected or untransfected LLC-PK1 cells did not yield resistant colonies under these conditions. Cells were maintained at $640 \mathrm{nM}$ vincristine selection.

Protein analysis. Purification of crude plasma membrane fractions and protein immunoblots were carried out as described (33), except that binding of monoclonal antibody C219 (36) was visualized using the enhanced chemiluminescence procedure (Amersham). C219 was a kind gift of Dr. S. Warnaar (Centocor Europe).

Transport assays. Transport assays were carried out as described (27) with minor modifications. Complete medium including L-glutamine, penicillin, streptomycin, and fetal calf serum was used throughout. Cells were seeded on microporous polycarbonate membrane filters (3.0 $\mu \mathrm{m}$ pore size, $24.5-\mathrm{mm}$ diameter, Transwell ${ }^{\mathrm{TM}} 3414$, Costar ${ }^{\circledR}$ ) at a density of $2 \times 10^{6}$ cells per well for LLC-PK1, L-MDR1, and L-mdr1a, respectively. The cells were grown for $3 \mathrm{~d}$ in complete medium with one medium replacement. 1-2 $\mathrm{h}$ before the start of the experiment medium at both the apical and the basal side of the monolayer was replaced with $2 \mathrm{ml}$ of complete medium. The experiment was started $(t=0)$ by replacing the medium at either the apical or the basal side of the cell layer with $2 \mathrm{ml}$ of complete medium containing the appropriate concentration of the radiolabeled drug (at $0.25 \mu \mathrm{Ci} / \mathrm{ml}$ ), and ${ }^{14} \mathrm{C}$-labeled inulin $(0.025 \mu \mathrm{Ci} / \mathrm{ml}, 4.2 \mu \mathrm{M})$. The cells were incubated at $37^{\circ} \mathrm{C}$ in $5 \% \mathrm{CO}_{2}$, and $50-\mu \mathrm{l}$ aliquots were taken from each compartment at 1 , 2,3 , and $4 \mathrm{~h}$. The appearance of radioactivity in the opposite compartment was measured and presented as the fraction of total radioactivity added at the beginning of the experiment. Directional transport was measured in duplicate and presented with a range bar. The paracellular flux was monitored by the appearance of inulin $\left[{ }^{14} \mathrm{C}\right]$ carboxylic acid in
L 11 1a

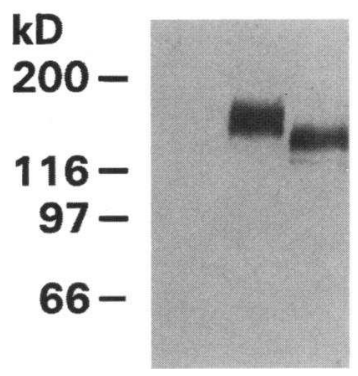

L 1 1a

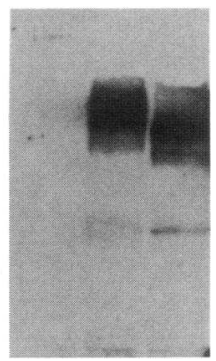

Figure 1. P-glycoprotein levels in membranes of LLC-PK1 $(L)$, LMDR1 (1), and L-mdrla ( 1a) cells. Crude membrane fractions from the respective clones were isolated and $10 \mu \mathrm{g}$ membrane protein was size fractionated in a $7.5 \%$ polyacrylamide gel containing $0.1 \%$ SDS. After electrophoretic blotting, P-glycoprotein was visualized by staining with monoclonal antibody C219. Left panel, short exposure, right panel, long exposure to reveal P-glycoprotein in LLC-PK1 membranes. Position and size of molecular weight markers are indicated.

the opposite compartment and was always $<1.5 \%$ of total radioactivity per $\mathrm{h}$.

Drug distribution studies. Drug distribution experiments were carried out as described (14). Male mice between 9 and $14 \mathrm{wk}$ of age were analyzed using 3,4 , or 5 mice in each group. Drugs for intravenous injection were formulated such, that $5 \mu$ l drug solution per gram body weight was injected into the tail vein of mice lightly anesthetized with diethyl ether (injection time: $5 \mathrm{~s}$ ). Unlabeled drug stocks were diluted in sterile $5 \%(\mathrm{wt} / \mathrm{vol}) \mathrm{D}$-glucose solution to obtain the appropriate concentration for injection $(0.2 \mathrm{mg} / \mathrm{ml}$ or $0.04 \mathrm{mg} / \mathrm{ml})$. Morphine. $\mathrm{HCl}$ stock $(1 \mathrm{mg} / \mathrm{ml})$ was dissolved in $5 \%$ D-glucose, dexamethasone and digoxin stocks $(1 \mathrm{mg} / \mathrm{ml}$ each) were dissolved in 1,2-propanediol, and cyclosporin A $(50 \mathrm{mg} / \mathrm{ml})$ was dissolved in polyoxyethylated ricinus oil $(650 \mathrm{mg} / \mathrm{ml})$ and ethanol $(33 \% \mathrm{vol} / \mathrm{vol})$. Labeled drugs were added after appropriate dilution of the drug stocks. Between 1 and $2.5 \mu \mathrm{Ci}$ was injected per mouse. At specific time points, mice were anesthetized and completely bled by orbital traction, thus removing most of the blood content of tissues. Heparin-plasma was obtained from the collected blood by centrifugation. Tissues were collected, weighed, and homogenized in $4 \%$ (wt/vol) bovine serum albumin. Blood-rich organs such as liver were dabbed on filter paper to remove most of the remaining blood. The contents of stomach, small intestine and colon were removed before homogenizing, whereas the gall bladder was processed with its bile content included. $200 \mu \mathrm{l}$ aliquots of plasma or homogenized tissue were transferred to Ultima gold counting fluid (Packard, Meriden, CT) and radioactivity was determined by liquid scintillation counting. The statistical significance of differences found between radioactivity levels in tissues of wild-type and mdrla $(-/-)$ mice was assessed using Student's two-tailed $t$ test.

\section{Results}

In vitro transport of drugs by the mouse mdrla and the human MDRI P-glycoprotein. To obtain a qualitative assessment of the capability of the mouse mdrla and the human MDR1 Pglycoprotein to translocate substrate drugs, we transfected the polarized pig kidney epithelial cell line LLC-PK1 with expression vectors containing $m d r l a$ or $M D R 1$ cDNA. Clones readily growing at high vincristine concentrations $(640 \mathrm{nM})$ were picked and their P-glycoprotein content was tested on an immunoblot. Fig. 1 shows that membrane fractions from representative clones contained similar levels of full-length MDR1 or mdr1a P-glycoprotein. In independent transfectants the mdrla 

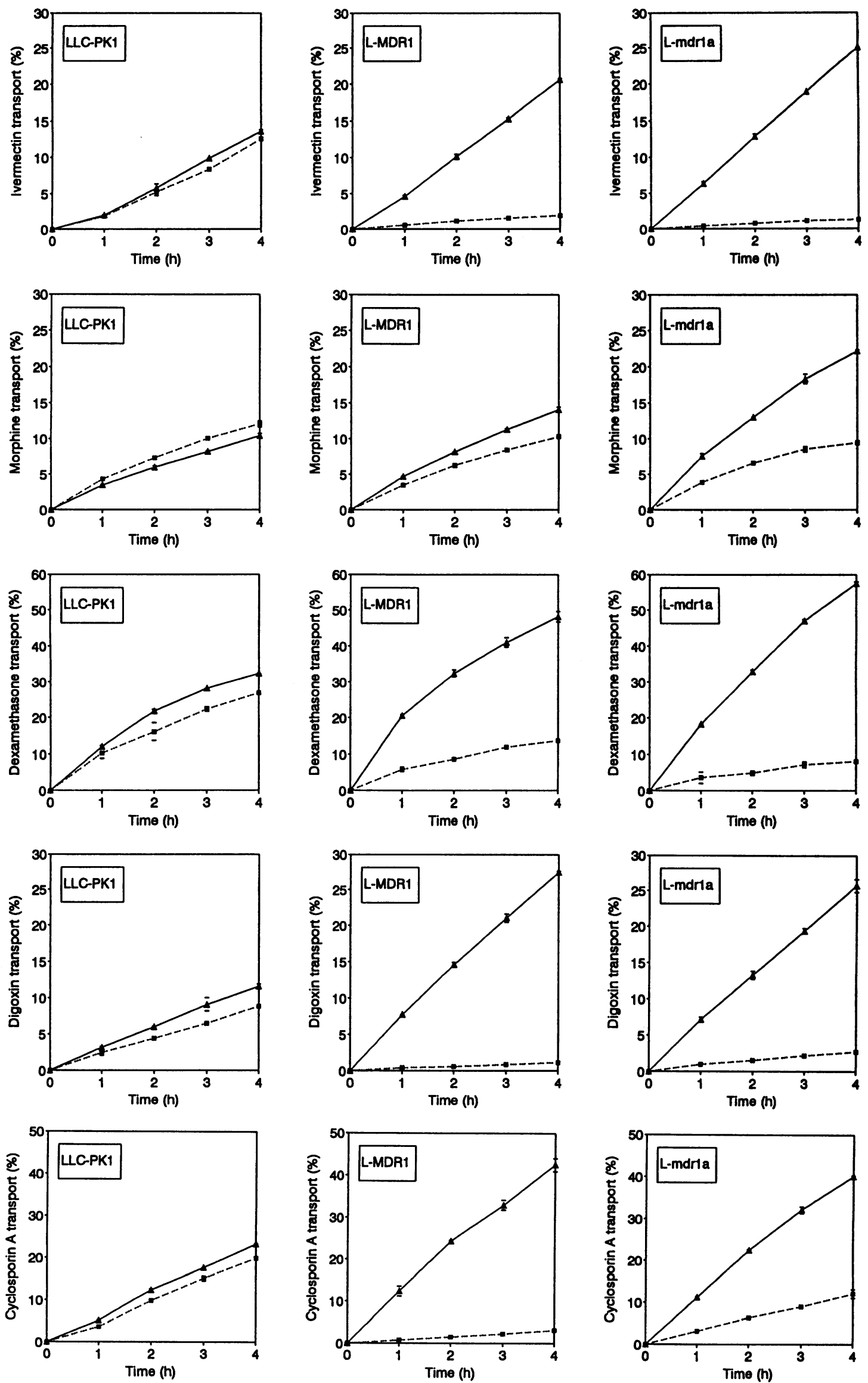
P-glycoprotein consistently migrated somewhat faster than the MDR1 P-glycoprotein, possibly owing to less extensive glycosylation, as the protein backbones have the same size. A small amount of porcine P-glycoprotein was detected in the parental cell line (27). These clones (LLC-PK1, L-MDR1, and Lmdr1a) were used to measure the transepithelial transport of radiolabeled compounds as described $(27,37)$. For details see Methods.

Fig. 2 illustrates that ivermectin, dexamethasone, digoxin and cyclosporin A were all readily transported in a polarized fashion by both the MDR1 and the mdrla P-glycoprotein. This is shown by the increased translocation from the basal to the apical side, and the decreased translocation from the apical to the basal side in the transfectants. The direct demonstration of ivermectin transport by both P-glycoproteins confirms our prediction based on ivermectin tissue distribution and toxicity in mdrla (-/-) mice (14) and indicates that the MDR1 Pglycoprotein will also affect ivermectin handling in humans. Morphine was transported to a moderate extent by the mdrla clone, and marginally by the MDR 1 clone. Lowering the morphine concentration from $2 \mu \mathrm{M}$ to $50 \mathrm{nM}$ or even $5 \mathrm{nM}$ did not improve the fractional transport capacity (not shown), indicating that the low transport rate observed was rather due to inefficient translocation of morphine (low apparent $V_{\max }$ ), than due to saturation of P-glycoprotein activity. Relatively inefficient transport of morphine as detected by reduced accumulation in cells was also reported for hamster P-glycoprotein (26). Like for morphine, lowering the concentration of dexamethasone or digoxin to 50 or $100 \mathrm{nM}$ did not significantly alter the fractional transport by these clones (not shown), indicating that the apparent $K_{\mathrm{m}}$ for these drugs in this system is higher than $2 \mu \mathrm{M}$. Vectorial transport by the human MDR1 P-glycoprotein across epithelial cell layers was demonstrated before for dexamethasone, digoxin, and cyclosporin A (27-29), although the clearly decreased translocation of cyclosporin A from apical to basal compartment (see Fig. 2) was not observed previously (29, 38 ). This is of importance, as the apical to basal drug transport more or less models the situation relevant for the accumulation of drugs in the brain in vivo (see below).

The data for the parental cell line also give an indication for the ease with which different compounds can passively diffuse through an epithelial cell layer: ivermectin, morphine and digoxin diffused with a moderate rate (3-4\% per hour), cyclosporin A with a higher rate (5-6\% per hour), and dexamethasone with a still higher rate $(7.5-9 \%$ per hour). These intrinsic properties of drugs may also affect their distribution and excretion properties in intact organisms, and the extent to which their handling is affected by MDR1-type P-glycoproteins.

Distribution of drugs in mdrla $(-/-)$ and $(+/+)$ mice. We have shown previously that $\operatorname{mdrla}(-/-)$ mice display a much higher accumulation of ivermectin and vinblastine in the brain than wild-type mice. In addition, vinblastine was eliminated more slowly from plasma and from several other organs such as heart, kidney, and liver (14). These findings indicate
Table I. Tissue Levels of Radioactivity in mdrla (+/+) and (-/-) Mice $4 \mathrm{~h}$ after Intravenous Injection of $\left[{ }^{3} \mathrm{H}\right]$ Morphine $(0.2 \mathrm{mg} / \mathrm{kg})$

\begin{tabular}{lccc}
\hline \multicolumn{1}{c}{ Tissue } & mdrla $(+/+)$ & mdrla $(-/-)$ & $\begin{array}{c}\text { Ratio } \\
(-/-):(+/+)\end{array}$ \\
\hline Brain & $5.3 \pm 1.9$ & $8.9 \pm 1.9$ & $1.7^{*}$ \\
Muscle & $6.4 \pm 2.3$ & $8.0 \pm 3.4$ & 1.3 \\
Heart & $9.2 \pm 2.7$ & $10.5 \pm 3.0$ & 1.1 \\
Kidney & $48.5 \pm 18.5$ & $37.6 \pm 10.9$ & 0.8 \\
Liver & $30.5 \pm 9.5$ & $32.9 \pm 7.3$ & 1.1 \\
Gall bladder & $527 \pm 326$ & $1154 \pm 412$ & $2.2^{*}$ \\
Lung & $18.7 \pm 5.5$ & $20.6 \pm 4.6$ & 1.1 \\
Stomach & $21.7 \pm 11.3$ & $18.3 \pm 6.4$ & 0.8 \\
Small intestine & $49.3 \pm 17.6$ & $36.4 \pm 8.3$ & 0.7 \\
Colon & $84.3 \pm 29.0$ & $52.7 \pm 13.5$ & 0.6 \\
Testis & $21.0 \pm 15.0$ & $14.0 \pm 2.4$ & 0.7 \\
Spleen & $13.8 \pm 4.6$ & $15.1 \pm 2.8$ & 1.1 \\
Thymus & $13.8 \pm 4.8$ & $10.4 \pm 3.0$ & 0.8 \\
Plasma & $10.9 \pm 4.0$ & $12.4 \pm 3.5$ & 1.1 \\
& & & \\
\hline
\end{tabular}

Results are expressed as means \pm SD $(n-1)$ in ng/gram tissue $\left(\left[{ }^{3} \mathrm{H}\right]\right.$ morphine equivalent). Four or five mice were analyzed in each group. ${ }^{*} P$ $<0.05$.

that a marked effect of mdrla deficiency in the blood-brain barrier for a certain drug will probably predict an overall effect on tissue distribution and pharmacokinetics of this drug.

To rapidly screen whether the handling of certain drugs will be affected by P-glycoprotein activity in vivo, we administered radiolabeled drugs intravenously to $m d r l a(-/-)$ and wildtype mice, and determined the tissue distribution of total radioactivity at certain time points. To limit complications by metabolism of drugs, we concentrated on a relatively early time point ( $4 \mathrm{~h}$ after injection). Table I shows the results obtained with a low dose of $\left[{ }^{3} \mathrm{H}\right]$ morphine $(0.2 \mathrm{mg} / \mathrm{kg})$. Whereas in vitro the mdrla P-glycoprotein demonstrated a limited transport of this drug, no significant differences were observed between $m d r l a$ $(-/-)$ and $(+/+)$ mice, except for the brain of mdrla $(-/-)$ mice which accumulated somewhat more $\left[{ }^{3} \mathrm{H}\right]$ morphine as detected by total radioactivity. The effect was limited, and in line with this finding, a small-scale acute toxicity test indicated that mdrla $(-/-)$ mice have an $\mathrm{LD}_{50}$ for morphine comparable with that of wild-type mice (data not shown).

For $\left[{ }^{3} \mathrm{H}\right]$ dexamethasone at low dose $(0.2 \mathrm{mg} / \mathrm{kg})$ we observed a significant difference in brain concentration $4 \mathrm{~h}$ after injection, although it was fairly moderate $(2.5$-fold, see Table II). At the same time, plasma levels were comparable between mdrla $(-I-)$ and $(+/+)$ mice, and the levels in all other tissues measured did not differ significantly. As dexamethasone fairly rapidly permeates membranes (see Fig. 2) we considered the possibility that it might have diffused already from the brain even in the absence of mdrla P-glycoprotein. We therefore

Figure 2. Transepithelial transport of ${ }^{3} \mathrm{H}$-labeled drugs in LLC-PK1, L-MDR1, and L-mdr1a monolayers. $\left[{ }^{3} \mathrm{H}\right]$ ivermectin was tested at $50 \mathrm{nM}$ concentration, all other drugs at $2 \mu \mathrm{M}$. At $t=0$, radioactive drug was applied in one compartment (basal or apical), and the percentage of radioactivity appearing in the opposite compartment at $t=1,2,3$, and $4 \mathrm{~h}$ was measured and plotted. Experiments were done in duplicate. Small bars around the average value indicate the measured values. ( $\square$, dashed/dotted line): translocation from apical to basal compartment. ( $\Lambda$, continuous line): translocation from basal to apical compartment. Note that for different drugs different percentage scales were used to plot transport. 
Table II. Tissue Levels of Radioactivity in mdrla $(+/+)$ and $(-/-)$ Mice 4 h after Intravenous Injection of $\left[^{3} \mathrm{H}\right]$ Dexamethasone $(0.2 \mathrm{mg} / \mathrm{kg})$

\begin{tabular}{lccc}
\hline \multicolumn{1}{c}{ Tissue } & mdrla $(+/+)$ & mdrla $(-/-)$ & $\begin{array}{c}\text { Ratio } \\
(-/-):(+/+)\end{array}$ \\
\hline Brain & $4.9 \pm 0.6$ & $12.2 \pm 2.1$ & $2.5^{\S}$ \\
Muscle & $11.1 \pm 2.3$ & $10.6 \pm 2.1$ & 1.0 \\
Heart & $17.6 \pm 4.6$ & $13.6 \pm 3.9$ & 0.8 \\
Kidney & $38.0 \pm 2.8$ & $45.7 \pm 2.2$ & 1.2 \\
Liver & $824 \pm 54$ & $904 \pm 168$ & 1.1 \\
Gall bladder & $5231 \pm 3852$ & $8899 \pm 3725$ & 1.7 \\
Lung & $21.6 \pm 4.6$ & $16.7 \pm 2.9$ & 0.8 \\
Colon & $73.3 \pm 6.9$ & $98.7 \pm 19.9$ & 1.3 \\
Testis & $11.7 \pm 2.7$ & $14.3 \pm 3.6$ & 1.2 \\
Spleen & $15.5 \pm 4.4$ & $14.6 \pm 4.5$ & 0.9 \\
Plasma & $17.2 \pm 2.9$ & $17.2 \pm 2.5$ & 1.0 \\
\hline
\end{tabular}

Results are expressed as means $\pm \mathrm{SD}(\mathrm{n}-1)$ in $\mathrm{ng} / \mathrm{g}$ tissue $\left(\left[{ }^{3} \mathrm{H}\right]\right.$ Dexamethasone equivalent). Three mice were analyzed in each group (five for brain and plasma). ${ }^{8} P<0.001$

also tested brain and plasma levels at earlier time points after injection. However, also 30 and $60 \mathrm{~min}$ after injection of $\left[{ }^{3} \mathrm{H}\right]$ dexamethasone the brain levels of total radioactivity were roughly threefold higher in mdrla $(-/-)$ mice, whereas the plasma levels in $(+/+)$ and $(-/-)$ mice were comparable (data not shown). This suggests that the mdrla P-glycoprotein has a clear, but moderate effect on the brain penetration of $\left[{ }^{3} \mathrm{H}\right]$ dexamethasone. At a higher dose of $\left[{ }^{3} \mathrm{H}\right]$ dexamethasone $(1 \mathrm{mg} / \mathrm{kg})$ the difference in brain concentration $4 \mathrm{~h}$ after injection was reduced to 1.8 -fold, which was no longer significant (data not shown).

Administration of $\left[{ }^{3} \mathrm{H}\right]$ digoxin at a dose of $1 \mathrm{mg} / \mathrm{kg}$ resulted in a strikingly (35-fold) higher accumulation of total radioactivity in brain of mdrla $(-/-)$ mice compared to wild-type mice $4 \mathrm{~h}$ after injection (Table III). At the same time, the concentration in plasma and in most tissues was roughly twofold higher in mdrla $(-/-)$ mice, suggesting an overall decreased elimination rate of this drug. These differences are rather similar to those seen previously with vinblastine at a dose of $1 \mathrm{mg} / \mathrm{kg}$ (14), indicating that the tissue distribution of $\left[{ }^{3} \mathrm{H}\right]$ digoxin is roughly as much affected by mdrla P-glycoprotein as that of the good P-glycoprotein substrate vinblastine.

Finally, we tested the tissue distribution of the immunosuppressive drug $\left[{ }^{3} \mathrm{H}\right]$ cyclosporin $\mathrm{A}$ at 4,8 , and $24 \mathrm{~h}$ after intravenous injection of a dose of $1 \mathrm{mg} / \mathrm{kg}$ (Tables IV, V, and VI, respectively). Again, we observed a very marked increase in accumulation of total radioactivity in the brain of mdrla $(-/-)$ mice compared to mdrla $(+/+)$ mice $(17-, 26-$, and 55 -fold, respectively, at 4,8 , and $24 \mathrm{~h}$ after administration). The difference in plasma concentration also increased with time, from 1.4-fold after $4 \mathrm{~h}$, to 1.9-fold after $24 \mathrm{~h}$, indicating that the overall elimination of $\left[{ }^{3} \mathrm{H}\right]$ cyclosporin $\mathrm{A}$ is diminished in mdrla $(-1-)$ mice. With a few exceptions, most tissues followed the trend in plasma concentration. Testis of mdrla $(-/-)$ mice initially accumulated significantly more $\left[{ }^{3} \mathrm{H}\right]-$ cyclosporin A (total radioactivity) relative to plasma concentration, but this effect dissipated over time. In contrast, muscle, gall bladder and especially small intestine of mdrla (-/-)
Table III. Tissue Levels of Radioactivity in mdrla $(+/+)$ and $(-/-)$ Mice $4 h$ after Intravenous Injection of $\left[{ }^{3} \mathrm{H}\right]$ Digoxin $(1 \mathrm{mg} / \mathrm{kg})$

\begin{tabular}{lccc}
\hline \multicolumn{1}{c}{ Tissue } & $m d r l a(+/+)$ & $m d r l a(-/-)$ & $\begin{array}{c}\text { Ratio } \\
(-l-):(+/+)\end{array}$ \\
\hline Brain & $55 \pm 22$ & $1939 \pm 207$ & $35.3^{\S}$ \\
Muscle & $745 \pm 135$ & $1094 \pm 103$ & $1.5^{*}$ \\
Heart & $445 \pm 130$ & $842 \pm 53$ & $1.9^{\ddagger}$ \\
Kidney & $612 \pm 327$ & $1163 \pm 261$ & 1.9 \\
Liver & $943 \pm 422$ & $1899 \pm 631$ & 2.0 \\
Gall bladder & $31436 \pm 12341$ & $54754 \pm 24489$ & 1.7 \\
Lung & $358 \pm 82$ & $778 \pm 175$ & $2.2^{\ddagger}$ \\
Stomach & $378 \pm 77$ & $589 \pm 93$ & $1.6^{*}$ \\
Small intestine & $1270 \pm 154$ & $1415 \pm 132$ & 1.1 \\
Colon & $1001 \pm 61$ & $675 \pm 152$ & $0.7^{*}$ \\
Testis & $213 \pm 83$ & $593 \pm 169$ & $2.8^{*}$ \\
Spleen & $216 \pm 48$ & $492 \pm 78$ & $2.3^{\ddagger}$ \\
Thymus & $214 \pm 36$ & $476 \pm 44$ & $2.2^{\S}$ \\
Plasma & $669 \pm 152$ & $1259 \pm 338$ & $1.9^{*}$ \\
& & & \\
\hline
\end{tabular}

Results are expressed as means \pm SD $(n-1)$ in $n g / g$ tissue $\left(\left[{ }^{3} \mathrm{H}\right]\right.$ digoxin equivalent). Three or four mice were analyzed in each group. $* P$ $<0.05 ;{ }^{\ddagger} P<0.01 ;{ }^{8} P<0.001$.

mice demonstrated gradually increasing differences over time, even when corrected for the plasma concentrations from 4 to 8 to $24 \mathrm{~h}$. Intravenous injection of vinblastine likewise resulted in comparatively increased levels in muscle, small intestine, and testis of mdrla (-l-) mice (14), although with that drug all effects were already observed $4 \mathrm{~h}$ after injection. Interestingly, the lymphoid organs (spleen, thymus, lymph nodes), containing part of the main clinical targets of cyclosporin A

Table IV. Tissue Levels of Radioactivity in mdrla $(+/+)$ and $(-/-)$ mice $4 \mathrm{~h}$ after Intravenous Injection of $\left[{ }^{3} \mathrm{H}\right]$ Cyclosporin $A$ ( $1 \mathrm{mg} / \mathrm{kg}$ )

\begin{tabular}{lccc}
\hline \multicolumn{1}{c}{ Tissue } & mdrla $(+/+)$ & mdrla $(-/-)$ & $\begin{array}{c}\text { Ratio } \\
(-/-):(+/+)\end{array}$ \\
\hline Brain & $10.5 \pm 0.7$ & $178 \pm 10$ & $17.0^{\S}$ \\
Muscle & $95 \pm 18$ & $169 \pm 50$ & 1.8 \\
Heart & $302 \pm 10$ & $481 \pm 84$ & $1.6^{*}$ \\
Kidney & $1402 \pm 205$ & $1457 \pm 195$ & 1.0 \\
Liver & $5320 \pm 421$ & $6397 \pm 1431$ & 1.2 \\
Gall bladder & $6552 \pm 3823$ & $3621 \pm 254$ & 0.6 \\
Lung & $604 \pm 40$ & $707 \pm 131$ & 1.2 \\
Stomach & $852 \pm 206$ & $1199 \pm 371$ & 1.4 \\
Small intestine & $1070 \pm 149$ & $2052 \pm 315$ & $1.9^{\ddagger}$ \\
Colon & $538 \pm 51$ & $882 \pm 72$ & $1.6^{\ddagger}$ \\
Testis & $57 \pm 12$ & $148 \pm 2$ & $2.6^{\S}$ \\
Spleen & $708 \pm 20$ & $1075 \pm 142$ & $1.5^{*}$ \\
Thymus & $483 \pm 162$ & $547 \pm 77$ & 1.1 \\
Lymph nodes & $611 \pm 103$ & $826 \pm 122$ & 1.4 \\
Plasma & $38 \pm 2$ & $54 \pm 10$ & 1.4 \\
& & & \\
\hline
\end{tabular}

Results are expressed as means \pm SD (n-1) in $n g / g$ tissue ( $\left[{ }^{3} \mathrm{H}\right]$ cyclosporin A equivalent). Three mice were analyzed in each group. ${ }^{*} P<0.05 ;{ }^{\ddagger} P<0.01 ;{ }^{\S} P<0.001$. 
Table V. Tissue Levels of Radioactivity in mdrla $(+/+)$ and $(-/-)$ Mice $8 \mathrm{~h}$ after Intravenous Injection of $\left.I^{3} \mathrm{H}\right]$ Cyclosporin $A$ (1 $\mathrm{mg} / \mathrm{kg}$ )

\begin{tabular}{lccc}
\hline \multicolumn{1}{c}{ Tissue } & mdrla $(+/+)$ & mdrla $(-/-)$ & $\begin{array}{c}\text { Ratio } \\
(-/-):(+/+)\end{array}$ \\
\hline Brain & $9.1 \pm 3.2$ & $239 \pm 47$ & $26.3^{\ddagger}$ \\
Muscle & $54 \pm 1$ & $124 \pm 56$ & 2.3 \\
Heart & $153 \pm 36$ & $231 \pm 41$ & 1.5 \\
Kidney & $716 \pm 166$ & $621 \pm 123$ & 0.9 \\
Liver & $4782 \pm 1371$ & $3950 \pm 1290$ & 0.8 \\
Gall bladder & $7820 \pm 3213$ & $11859 \pm 8653$ & 1.5 \\
Lung & $246 \pm 56$ & $318 \pm 73$ & 1.3 \\
Stomach & $669 \pm 104$ & $491 \pm 73$ & 0.7 \\
Small intestine & $716 \pm 153$ & $2471 \pm 203$ & $3.4^{\S}$ \\
Colon & $518 \pm 109$ & $936 \pm 324$ & 1.8 \\
Testis & $84 \pm 5$ & $183 \pm 13$ & $2.2^{\S}$ \\
Spleen & $403 \pm 114$ & $583 \pm 131$ & 1.4 \\
Thymus & $313 \pm 98$ & $418 \pm 38$ & 1.3 \\
Lymph nodes & $528 \pm 125$ & $686 \pm 151$ & 1.3 \\
Plasma & $14.3 \pm 3.9$ & $21 \pm 4$ & 1.5 \\
& & & \\
\hline
\end{tabular}

Results are expressed as means \pm SD (n-1) in $\mathrm{ng} / \mathrm{g}$ tissue

([ $\left.{ }^{3} \mathrm{H}\right]$ cyclosporin $A$ equivalent). Three mice were analyzed in each group. ${ }^{*} P<0.05 ;{ }^{\ddagger} P<0.01 ;{ }^{8} P<0.001$.

(lymphocytes) did not demonstrate clear differences in accumulation independent of the plasma concentration.

\section{Discussion}

Our results indicate that the tissue distribution and pharmacokinetics of the heart glycoside digoxin and the immunosuppressive drug cyclosporin $\mathrm{A}$ are strongly affected by the mouse mdrla P-glycoprotein activity. Tissue distribution of the glucocorticoid dexamethasone is moderately affected, whereas morphine handling appears to be hardly affected in vivo. In vitro, the human MDR1 P-glycoprotein demonstrated a comparable ability to transport ivermectin, dexamethasone, digoxin and cyclosporin A as the mdr1a P-glycoprotein (Fig. 2), suggesting that also in humans the handling of these drugs can be markedly affected by P-glycoprotein activity. In fact, the drug distribution and pharmacokinetic effects in the mdrla $(-/-)$ mice will probably be limited by the continuing presence of the mdrlb P-glycoprotein, especially as this protein is upregulated in liver and kidney of mdrla $(-/-)$ mice (14). Partial or complete blocking of the single drug-transporting MDR1 P-glycoprotein in humans might therefore have even more outspoken pharmacological effects than those observed in mdrla (-/-) mice. The limited effects on morphine handling by the mdr1a Pglycoprotein in mice, combined with the very low in vitro transport by the MDR1 P-glycoprotein suggest that this drug will be hardly affected by P-glycoprotein activity in humans. However, it should be noted that some of the compounds tested may undergo relatively rapid metabolism in mice. If the resulting (radiolabeled) metabolites are not affected by P-glycoprotein, we may underestimate the effect of the absence of mdrla Pglycoprotein by analyzing total radioactivity. This could for instance apply to morphine and dexamethasone. A definitive assessment of the significance of P-glycoprotein for the distribu-
Table VI. Tissue Levels of Radioactivity in mdrla $(+/+)$ and $(-/-)$ Mice 24 h after Intravenous Injection of $\left[{ }^{3} \mathrm{H}\right]$ Cyclosporin A (1 $\mathrm{mg} / \mathrm{kg})$

\begin{tabular}{lccc}
\hline \multicolumn{1}{c}{ Tissue } & mdrla $(+/+)$ & mdrla $(-/-)$ & $\begin{array}{c}\text { Ratio } \\
(-/-):(+/+)\end{array}$ \\
\hline Brain & $2.5 \pm 0.9$ & $138 \pm 6$ & $55.2^{8}$ \\
Muscle & $5.8 \pm 2.0$ & $23 \pm 6$ & $4.0^{\ddagger}$ \\
Heart & $21 \pm 6$ & $43 \pm 3$ & $2.1^{\ddagger}$ \\
Kidney & $88 \pm 17$ & $135 \pm 14$ & $1.5^{*}$ \\
Liver & $857 \pm 280$ & $1164 \pm 73$ & 1.4 \\
Gall bladder & $753 \pm 134$ & $3491 \pm 402$ & $4.6^{\ddagger}$ \\
Lung & $33 \pm 12$ & $70 \pm 8$ & $2.1^{*}$ \\
Stomach & $401 \pm 174$ & $461 \pm 284$ & 1.1 \\
Small intestine & $161 \pm 46$ & $1334 \pm 204$ & $8.3^{8}$ \\
Colon & $153 \pm 36$ & $252 \pm 32$ & $1.7^{*}$ \\
Testis & $63 \pm 6$ & $116 \pm 35$ & 1.8 \\
Spleen & $66 \pm 3$ & $140 \pm 46$ & $2.1^{*}$ \\
Thymus & $163 \pm 43$ & $200 \pm 58$ & 1.2 \\
Lymph nodes & $108 \pm 24$ & $196 \pm 10$ & $1.8^{\ddagger}$ \\
Plasma & $3.4 \pm 0.7$ & $6.4 \pm 0.7$ & $1.9^{\ddagger}$ \\
& & & \\
\hline
\end{tabular}

Results are expressed as means \pm SD (n-1) in $n g / g$ tissue

( $\left[{ }^{3} \mathrm{H}\right]$ cyclosporin A equivalent). Three mice were analyzed in each group. ${ }^{*} P<0.05 ;{ }^{\ddagger} P<0.01 ;{ }^{\S} P<0.001$.

tion of these compounds must therefore await a more extensive analysis using specific detection of the parent drugs.

Our finding that the in vivo handling of both digoxin and cyclosporin A is strongly affected by MDR1-type P-glycoprotein sheds new light on many pharmacological interactions that have been observed in clinical practice. The heart glycoside digoxin, widely used in the treatment of congestive heart failure, has a narrow therapeutic window: a moderate increase in concentration relative to the therapeutic plasma level will result in dangerous toxicity to the heart. Interestingly, co-administration of many other drugs was found to result in increased plasma levels of digoxin. Some striking examples are the anti-arrhythmic drugs quinidine and amiodarone, the calcium channel blockers verapamil and diltiazem, and the anti-malarial drug quinine (30). In retrospect, most of these drugs turn out to be compounds that can inhibit P-glycoprotein activity (21). In fact, some of these drugs (verapamil, quinidine, quinine) have even been used in clinical trials because of their ability to reverse Pglycoprotein-mediated multidrug-resistance in chemotherapy resistant tumors (24). In view of our findings it is likely that the observed drug interactions are due at least in part to inhibition of P-glycoprotein activity by the co-administered drugs, resulting in altered tissue distribution and diminished elimination of digoxin. This possibility was previously proposed by Tanigawara et al. (28) based on their finding that the human MDR1 Pglycoprotein can transport digoxin in vitro.

The digoxin concentration in brain is very markedly affected in $m d r l a(-/-)$ mice. In view of the side effects of digoxin treatment on the central nervous system of humans (30), one might expect severely increased toxicity of digoxin in $\mathrm{mdrla}$ $(-/-)$ mice. However, a small-scale oral toxicity test revealed only a roughly fourfold increase in sensitivity (not shown). This is probably due to the fact that the mouse form of the pharmacological target of digoxin (the $\mathrm{Na}^{+} / \mathrm{K}^{+}$-ATPase) is 
unusually resistant to digoxin (39). Digoxin toxicity in mice is therefore fundamentally different from that in humans.

A more or less similar situation as for digoxin holds true for the immunosuppressive drug cyclosporin A. Whereas this drug has so far been used mainly in relation to P-glycoprotein for its ability to inhibit the transport of other drugs (even in clinical trials of MDR reversal, see reference 24), it now appears to be itself an excellent $P$-glycoprotein substrate in vivo: its pharmacological disposition is to a considerable extent influenced by P-glycoprotein activity. Drugs that can increase plasma levels of cyclosporin A upon co-administration include ketoconazole, erythromycin, diltiazem, nicardipine, and verapamil (30; manufacturer's information). All of these drugs have been shown to act as P-glycoprotein reversal agents $(21,40)$. In fact, in some clinical settings, after renal transplantation, diltiazem is purposely co-administered with cyclosporin A to allow an effective plasma level of this expensive drug to be reached with lower drug dosages. As cyclosporin A is mainly eliminated via the liver, it is thought that these drug interactions are the consequence of competition for degradation by cytochrome P450(3A) enzymes in the liver (30, 41-43). However, our data show that competition for P-glycoprotein activity might also contribute to the observed effects. Following this line of reasoning, the pharmacological behavior of cyclosporin A coadministered as a reversal agent during chemotherapy with cytotoxic P-glycoprotein substrates might in turn also be affected by the presence of these drugs, depending on their relative ability to compete for P-glycoprotein transport.

The marked tissue distribution effects observed for cyclosporin A and (to a lesser extent) dexamethasone indicate that the accumulation of these compounds in individual cells in the organism is also affected by the presence of P-glycoprotein in the membrane of these cells. For cyclosporin A, this may in itself be of importance, as the clinical targets of this immunosuppressive drug (lymphocytes: CD4+ helper $\mathrm{T}$ cells and CD8+ suppressor or cytolytic $\mathrm{T}$ cells) (44) also contain functional P-glycoprotein (45). Variation in P-glycoprotein levels in these cells between individual patients might explain in part the somewhat variable plasma levels of cyclosporin A needed to obtain an effective suppression of allograft rejection. One might even speculate that the beneficial effect of adding diltiazem to cyclosporin A regimens in renal transplantation (44) is partly the consequence of improved penetration of cyclosporin A into its target cells. As for dexamethasone, it has been shown that in a mouse thymoma cell line the mdrlb P-glycoprotein can confer resistance against this drug (46). Clinical efficacy of this drug may therefore also be affected by P-glycoprotein at the cellular level.

Taken together, our results confirm and extend the potential in vivo pharmacological importance of MDR1-type P-glycoproteins for many different drugs, including both those excreted primarily via the kidney (e.g., digoxin) and those eliminated primarily via the liver (e.g., cyclosporin A). Hopefully, this knowledge will contribute to the improved pharmacological treatment of cancer as well as other diseases.

\section{Acknowledgments}

We thank our colleagues for critical reading of the manuscript. We are indebted to A. J. Schrauwers for excellent biotechnical assistance, Dr P. Gros (McGill University, Montreal, Canada) for providing the mouse mdr cDNAs, Drs J. M. Schaeffer and L. H. T. van der Ploeg (Merck
Research Laboratories, $\mathrm{NJ}$ ) for providing labeled ivermectin and Dr. S. Warnaar (Centocor Europe, Leiden, The Netherlands) for providing monoclonal antibody C219.

This work was supported in part by grant NKI $92-41$ of the Dutch Cancer Society to P. Borst.

\section{References}

1. Juliano, R. L., and V. Ling. 1976. A surface glycoprotein modulating drug permeability in Chinese hamster ovary cell mutants. Biochim. Biophys. Acta. 455:152-162.

2. Gros, P., J. Croop, and D. Housman. 1986. Mammalian multidrug resistance gene: complete cDNA sequence indicates strong homology to bacterial transport proteins. Cell. 47:371-380.

3. Chen, C., J. E. Chin, K. Ueda, D. P. Clark, I. Pastan, M. M. Gottesman, and I. B. Roninson. 1986. Internal duplication and homology with bacterial transport proteins in the $m d r 1$ (P-glycoprotein) gene from multidrug-resistant human cells. Cell. 47:381-389.

4. Endicott, J. A., and V. Ling. 1989. The biochemistry of P-glycoproteinmediated multidrug resistance. Annu. Rev. Biochem. 58:137-171.

5. Gottesman, M. M., and I. Pastan. 1993. Biochemistry of multidrug resistance mediated by the multidrug transporter. Annu. Rev. Biochem. 62:385-427.

6. Thiebaut, F., T. Tsuruo, H. Hamada, M. M. Gottesman, I. Pastan, and M. C. Willingham. 1987. Cellular localization of the multidrug resistance gene product in normal human tissues. Proc. Natl. Acad. Sci. USA. 84:7735-7738.

7. Cordon-Cardo, C., J. P. O'Brien, D. Casals, L. Rittman-Grauer, J. L. Biedler, M. R. Melamed, and J. R. Bertino. 1989. Multidrug-resistance gene (P-glycoprotein) is expressed by endothelial cells at blood-brain barrier sites. Proc. Natl. Acad. Sci. USA. 86:695-698.

8. Sugawara, I., I. Kataoka, Y. Morishita, H. Hamada, T. Tsuruo, S. Itoyama, and S. Mori. 1988. Tissue distribution of P-glycoprotein encoded by a multidrugresistant gene as revealed by a monoclonal antibody, MRK16. Cancer Res. 48:1926-1929.

9. Hsu, S. I., L. Lothstein, and S. B. Horwitz. 1989. Differential overexpression of three mdr gene family members in multidrug-resistant $\mathrm{J} 774.2$ mouse cells. $J$. Biol. Chem. 264:12053-12062.

10. Devault, A., and P. Gros. 1990. Two members of the mouse mdr gene family confer multidrug resistance with overlapping but distinct drug specificities. Mol. Cell. Biol. 10:1652-1663.

11. Croop, J. M., M. Raymond, D. Haber, A. Devault, R. J. Arceci, P. Gros, and D. E. Housman. 1989. The three mouse multidrug resistance (mdr) genes are expressed in a tissue-specific manner in normal mouse tissue. Mol. Cell. Biol. 9:1346-1350.

12. Arceci, R. J., J. M. Croop, S. B. Horwitz, and D. Housman. 1988. The gene encoding multidrug resistance is induced and expressed at high levels during pregnancy in the secretory epithelium of the uterus. Proc. Natl. Acad. Sci. USA. 85:4350-4354.

13. Teeter, L. D., F. F. Becker, F. V. Chisari, D. Li, and M. T. Kuo. 1990. Overexpression of the multidrug resistance gene mdr 3 in spontaneous and chemically induced mouse hepatocellular carcinomas. Mol. Cell. Biol. 10:5728-5735.

14. Schinkel, A. H., J. J. M. Smit, O. van Tellingen, J. H. Beijnen, E. Wagenaar, L. van Deemter, C. A. A. M. Mol, M. A. van der Valk, E. C. RobanusMaandag, H. P. J. te Riele, A. J. M. Berns, and P. Borst. 1994. Disruption of the mouse mdrla P-glycoprotein gene leads to a deficiency in the blood-brain barrier and to increased sensitivity to drugs. Cell. 77:491-502.

15. Goldstein, L. J., H. Galski, A. Fojo, M. Willingham, S.-L. Lai, A. Gazdar, R. Pirker, A. Green, W. Crist, G. M. Brodeur, M. Lieber, J. Cossman, M. M. Gottesman, and I. Pastan. 1989. Expression of a multidrug resistance gene in human cancers. J. Natl. Cancer Inst. 81:116-124.

16. Chan, H. S. L., G. Haddad, P. S. Thorner, G. DeBoer, Y. P. Lin, N. Ondrusek, H. Yeger, and V. Ling. 1991. P-glycoprotein expression as a predictor of the outcome of therapy for neuroblastoma. N. Engl. J. Med. 325:1608-1614.

17. Gottesman, M. M. 1993. How cancer cells evade chemotherapy: sixteenth Richard and Hinda Rosenthal foundation award lecture. Cancer Res. 53:747754.

18. Tsuruo, T., H. Iida, S. Tsukagoshi, and Y. Sakurai. 1981. Overcoming of vincristine resistance in P388 leukemia in vivo and in vitro through enhanced cytotoxicity of vincristine and vinblastine by verapamil. Cancer Res. 41:19671972.

19. Slater, L. M., P. Sweet, M. Stupecky, and S. Gupta. 1986. Cyclosporin A reverses vincristine and daunorubicin resistance in acute lymphatic leukemia in vitro. J. Clin. Invest. 77:1405-1408.

20. Boesch, D., C. Gavériaux, B. Jachez, A. Pourtier-Manzanedo, P. Bollinger, and F. Loor. 1991. In vivo circumvention of P-glycoprotein-mediated multidrug resistance of tumor cells with SDZ PSC 833. Cancer Res. 51:4226-4233.

21. Ford, J. M., and W. N. Hait. 1990. Pharmacology of drugs that alter multidrug resistance in cancer. Pharmacol. Rev. 42:155-199.

22. Dalton, W. S., T. M. Grogan, P. S. Meltzer, R. J. Scheper, B. G. M. Durie, 
C. W. Taylor, T. P. Miller, and S. E. Salmon. 1989. Drug-resistance in multiple myeloma and non-Hodgkin's lymphoma: detection of P-glycoprotein and potentia circumvention by addition of verapamil to chemotherapy. J. Clin. Oncol. 7:415424.

23. Lum, B. L., S. Kaubisch, A. M. Yahanda, K. M. Adler, L. Jew, M. N Ehsan, N. A. Brophy, J. Halsey, M. P. Gosland, and B. I. Sikic. 1992. Alteration of etoposide pharmacokinetics and pharmacodynamics by cyclosporine in a phase I trial to modulate multidrug resistance. J. Clin. Oncol. 10:1635-1642.

24. Sikic, B. I. 1993. Modulation of multidrug resistance: at the threshold. $J$. Clin. Oncol. 11:1629-1635.

25. McLeod, H. L. 1994. Clinical reversal of the multidrug resistance phenotype: true tumor modulation or pharmacokinetic interaction? Eur. J. Cancer 30A:2039-2041.

26. Callaghan, R., and J. R. Riordan. 1993. Synthetic and natural opiates interact with P-glycoprotein in multidrug-resistant cells. J. Biol. Chem. 268:16059-16064.

27. Ueda, K., N. Okamura, M. Hirai, Y. Tanigawara, T. Saeki, N. Kioka, T. Komano, and R. Hori. 1992. Human P-glycoprotein transports cortisol, aldosterone, and dexamethasone, but not progesterone. J. Biol. Chem. 267:24248-24252.

28. Tanigawara, Y., N. Okamura, M. Hirai, M. Yasuhara, K. Ueda, N. Kioka, T. Komano, and R. Hori. 1992. Transport of digoxin by human P-glycoprotein expressed in a porcine kidney epithelial cell line (LLC-PK1). J. Pharm. Exp. Ther. 263:840-845.

29. Saeki, T., K. Ueda, Y. Tanigawara, R. Hori, and T. Komano. 1993. Human P-glycoprotein transports cyclosporin A and FK506. J. Biol. Chem. 268:6077 6080.

30. Gilman, A. G., T. W. Rall, A. S. Nies, and P. Taylor. 1991. The pharmacological basis of therapeutics. McGraw-Hill Book Co., Singapore. 1811 pp.

31. Choi, K., C. Chen, M. Kriegler, and I. B. Roninson. 1988. An altered pattern of cross-resistance in multidrug-resistant human cells results from spontaneous mutations in the mdr1 (P-glycoprotein) gene. Cell. 53:519-529.

32. Gros, P., R. Dhir, J. Croop, and F. Talbot. 1991. A single amino acid substitution strongly modulates the activity and substrate specificity of the mouse mdrl and mdr3 drug efflux pumps. Proc. Natl. Acad. Sci. USA. 88:7289-7293.

33. Schinkel, A. H., M. E. M. Roelofs, and P. Borst. 1991. Characterization of the human MDR3 P-glycoprotein and its recognition by P-glycoprotein-specific monoclonal antibodies. Cancer Res. 51:2628-2635.

34. Schinkel, A. H., S. Kemp, M. Dollé, G. Rudenko, and E. Wagenaar. 1993. $N$-glycosylation and deletion mutants of the human MDRI P-glycoprotein. $J$. Biol. Chem. 268:7474-7481.
35. Graham, F. L., and A. J. van der Eb. 1973. A new technique for the assay of infectivity of human adenovirus 5 DNA. Virology. 52:456-467.

36. Georges, E., G. Bradley, J. Gariepy, and V. Ling. 1990. Detection of Pglycoprotein isoforms by gene-specific monoclonal antibodies. Proc. Natl. Acad. Sci. USA. 87:152-156.

37. Horio, M., K.-v. Chin, S. J. Currier, S. Goldenberg, C. Williams, I. Pastan, M. M. Gottesman, and J. Handler. 1989. Transepithelial transport of drugs by the multidrug transporter in cultured Madin-Darby canine kidney cell epithelia. $J$. Biol. Chem. 264:14880-14884.

38. Shirai, A., M. Naito, T. Tatsuta, J. Dong, K. Hanaoka, K. Mikami, T. Ohhara, and T. Tsuruo. 1994. Transport of cyclosporin A across the brain capillary endothelial cell monolayer by P-glycoprotein. Biochim. Biophys. Acta. 1222:400404.

39. Czerwek, H., K. Hardebeck, F. Kaiser, W. Schaumann, and A. WohlfarthRibbentrop. 1971. $\beta$-Methyl-digoxin. II. Extracardiale Wirkungen bei enteraler und parenteraler Gabe. Arzneimittel-Forsch. 21:231-234.

40. Siegsmund, M. J., C. Cardarelli, I. Aksentijevich, Y. Sugimoto, I. Pastan, and M. M. Gottesman. 1994. Ketoconazole effectively reverses multidrug resistance in highly resistant KB cells. J. Urol. 151:485-491.

41. McMillan, M. A. 1989. Clinical Pharmacokinetics of cyclosporin. Pharmacol. Ther. 42:135-156.

42. Aoyama, T., S. Yamano, D. J. Waxman, D. P. Lapenson, U. A. Meyer, V. Fischer, R. Tyndale, T. Inaba, W. Kalow, H. V. Gelboin, and F. J. Gonzalez. 1989. Cytochrome P-450 hPCN3, a novel cytochrome P450 IIIA gene product that is differentially expressed in adult human liver. J. Biol. Chem. 264:1038810395 .

43. Pelkonen O., and D. D. Breimer. 1994. Role of environmental factors in the pharmacokinetics of drugs: considerations with respect to animal models, P450 enzymes, and probe drugs. In Handbook of Experimental PharmacologyVolume III. P. G. Welling and L. P. Balant, editors. Springer Verlag, Basel. 289332.

44. Suthanthiran, M., and T. B. Strom. 1994. Renal transplantation. N. Engl. J. Med. 331:365-375.

45. Klimecki, W. T., B. W. Futscher, T. M. Grogan, and W. S. Dalton. 1994. $\mathrm{P}$-glycoprotein expression and function in circulating blood cells from normal volunteers. Blood. 83:2451-2458.

46. Bourgeois, S., D. J. Gruol, R. F. Newby, and F. M. Rajah. 1993. Expression of an mdr gene is associated with a new form of resistance to dexamethasoneinduced apoptosis. Mol. Endocrinol. 7:840-851. 